\title{
The Study of EFL Teacher Discourse in Reading Skill Using Bloom's Cognitive Taxonomy
}

\author{
Zargham Ghabanchi \\ Ferdowsi University of Mashhad, Iran \\ E-mail: ghabanchi@um.ac.ir \\ Mostafa Morady Moghaddam (Corresponding author) \\ University of Tabriz, Iran \\ E-mail: mostafa_morady@yahoo.com
}

\begin{abstract}
Shirin Malekzadeh
Department of English Language, Urmia Branch, Islamic Azad University, Urmia, Iran E-mail: sh_malekzadeh196@yahoo.com
\end{abstract}

Received: June 3, 2011 Accepted: June 22, 2011 doi:10.5296/ijl.v3i1.812

\begin{abstract}
This article aims at investigating EFL teacher discourse while presenting reading skill. Moreover, the relationship between teacher discourse and learners' proficiency level as well as learners' cognitive state were studied based on Bloom's cognitive taxonomy. This paper sheds light on some important aspects of teacher-student interactions in reading comprehension skill. Thirty two EFL classes were observed and the way teachers interacted with learners while presenting reading activities was analyzed and teachers' voices were audio-recorded. This research was conducted on three phases; (1) pre-reading; (2) during-reading; and (3) after-reading. Using Bloom's taxonomy, the researchers found that most teachers use action verbs which are related to concrete end of the taxonomy regardless of the learners' level of proficiency and their cognitive state. The findings of this study made it clear that a) there is little congruency between teachers' discourse and learners' proficiency level; b) teacher discourse is so limited and is incapable to target higher-level thinking
\end{abstract}




\section{Macrothink}

International Journal of Linguistics ISSN 1948-5425 2011, Vol. 3, No. 1: E18

processes which are placed in more abstract levels in Bloom's taxonomy; and c) higher-level thinking processes are to a great degree dependent on learners' language proficiency.

Keywords: Teacher discourse, Reading skill, Bloom's cognitive taxonomy, Higher-level thinking 


\section{Background}

Having a journey back to the mid-1970s, one can recognize that as Neurolinguistic Programming (NLP) came into vogue in the world of language teaching, with it grew a concern for the effectiveness of communication and the undeniable influence that individuals can exercise on each other through verbal interaction. Proponents of NLP were interested to find out what it is about successful communicators that enables them to lead others (Richards $\&$ Rodgers, 2001). They investigated many therapists to find out the patterns they resort to in relating to their clients and in the quality of language they used. This was the first time that serious effort was done to discover influential features of language used between interlocutors. This investigation was mainly conducted to analyze the quality of talk between two persons.

A similar but more focused trend toward studying the usefulness of language appeared since the pioneering works of Bandler and Grinder (1982), but this time in the territory of language teaching in general, and in language classroom in particular. Undoubtedly, the classroom is one of the places that language plays a vital role in which there exists a kind of therapist/client relationship - the teacher establishes rapport to bring about personal change within the learners. It is argued that language shapes learning and influences the thought (Vygotsky, 1962). It is clear that, concluding from the aforementioned information, for every responsible teacher who is keen to improve the quality of his/her teaching, improving the quality of teacher discourse should be one of the priorities. Teachers should be able to have an initial view of how to establish rapport with learners (Mortiboys, 2005). At the first glance it seems quite impressive but learning how to relate to learners takes time and requires good knowledge.

The study of teacher discourse is a thriving field of inquiry. The effect of teacher discourse is not unknown to researchers and language teachers since it has a significant role on learners' success or failure. Millrood (2004) has studied the impact of NLP techniques in teachers' discourse on directing learners toward better understanding of the language. He mentioned that it is possible to improve teacher-learner congruence through a decent verbal interaction with the learners. Creating an optimal condition for a productive classroom interaction was the main purpose of his study. In another study, Inceçay (2010) analyzed the quality of a teacher's language use in a class of 16 Turkish young learners of English as a foreign language and found that there are two categories regarding teacher talk; construction and obstruction. Therefore, teachers can improve or hinder learning process through the language they use.

Some studies have delved into the relationship between teacher's supportive instructional discourse and learners' reports of self-regulation and positive coping (Turner, Meyer, Midgley, $\&$ Patrick, 2003). Many studies have advocated the influence of teacher discourse on learners' success. Webb, Nemer, and Ing (2006) conducted a research and concluded that the discourse modeled by the teacher is largely mirrored, to use the aforementioned researchers' word, in learners' behavior. 
Nevertheless, throughout this journey one can hardly see any investigation on the teachers' use of "action verbs" and its relationship with learners' proficiency level in reading skill in EFL classes. According to Krashen (1984), comprehensible input is the only pathway through which individuals can build a cognitive map of a second language and eventually this input leads to acquisition of L2. Krashen stated this notion as " $i+1$ hypothesis" in which he came to the realization that the input individuals receive should be tuned with their existing level of knowledge (Brown, 2007). In every EFL classroom situation, educators should take it into account that the language learners are exposed to should not be far beyond or much lower than their current competence otherwise it would have consequences both for the teacher and especially for the learners (Brown, 2007). It is not unlikely to see in a classroom that highly proficient learners become demotivated by the teacher's activities and questions and, on the other hand, beginners become frustrated with participating in mind-boggling classroom activities.

It is of paramount importance for EFL teachers to be aware of the characteristics of their discourse, for it is one of the most beneficial tools which is at the hand of teachers and has a great effect on reducing learners' affective filter. Therefore, teacher talk, defined as "the variety of language used by teachers when they are in the process of teaching" (Richards \& Schmidt, 2002, p. 543), is a significant tool to communicate with learners. Teacher discourse, therefore, can turn to Achilles' heel if educators do not match their discourse to learners' proficiency level. In every-day language teaching, educators use questions or introduce various activities. They may, for instance, ask learners to compare, differentiate, define, or paraphrase. However, the review of literature revealed that little research has been done in order to find out the quality of teacher discourse in presenting reading skill during its various phases-pre-reading, during-reading, and after-reading. Precise analysis is necessary to increase teacher effectiveness. In this article it is not intended to analyze the discourse according to political characters (Kumaravadivelu, 1999) but the use of action verbs in the discourse of teachers while presenting reading activities is investigated.

With the growing number of individuals learning English, researchers and teachers should take into account significant aspects of classroom discourse. Kumaravadivelu (2003a) discussed that "our first and foremost duty as teachers is to maximize learning opportunities for our learners" (p. 44). Teachers, therefore, should take it into account that they should be able to direct learners toward using the knowledge in new situations, creating examples, and sharing the information, to name a few; all these opportunities are largely, but not totally, affected by how the teacher manipulates his/her discourse.

\section{Purpose of the Study}

The main purpose of this article is to analyze teacher discourse according to Bloom's cognitive model, especially the action verbs, while teaching reading in EFL context. In general, this article covers the questions which are mentioned below: 
- Which areas of thinking process are eminent during different phases of teaching reading?

- Do the learners learn how to apply the knowledge they require when reading a passage?

- Does the instruction liberate learners or make them addicted to obey the teacher unquestionably?

- What is the main concern of teachers while teaching reading?

- What is the role of learners in different phases of reading activities?

\section{Method}

\subsection{Participants}

In order to find out the quality of teacher discourse in reading skill, thirty two classes (32 teachers) were observed during one term (approximately 45 days) and the interactions between teachers and the learners were investigated and their voices were audio-recorded. Twelve teachers were male and the rest were female. All of them were teaching English as a foreign language in different institutes in Mashhad, Iran. Ten teachers had a BA degree in teaching English; fourteen had a BA degree in English literature; four of them had BA in translation studies; and the rest had learned English in institutes and did not have university degree in English. These classes were conducted during autumn term. Learners were in various levels of proficiency-intermediate, upper-intermediate, and advanced. The main criteria which showed learners' proficiency level were the terms they had passed as well as their existing knowledge which was obtained from the teachers. Therefore, the study was conducted on three groups. The average age of learners was sixteen.

\subsection{Procedure}

The researchers studied the transcriptions of audio-recorded observations to discover the quality of teacher talk while presenting reading activities and its relation to learners various levels of proficiency. Therefore, teachers' use of action verbs in different phases of teaching reading along with the sentences the action verbs were used was chosen for precise investigation. According to Bloom's taxonomy of thinking process, there are specific verbs that are consistent with particular levels of thinking. To present a clear picture, Table 1 is used which is an adaptation from Shrum and Glisan (1994).

According to Bloom's taxonomy, all of the teachers' action verbs and the sentences in which they occur were chosen. Then, each action verb was placed under its own level of thinking. For instance, the word tell in teacher discourse is categorized under the knowledge level and the rest undertook the same procedure until the last action verb was placed in its own category. It should be mentioned that the action verbs provided in Table 1 are just a summary and for investigating more action verbs it is suggested to consult the source given or search through the internet. In each category there are some specific action verbs. This study aimed at providing a clear picture of EFL teachers' discourse while teaching reading with regard to learners' proficiency level based on Bloom's taxonomy. 
Table 1. Bloom's taxonomy of thinking processes

\begin{tabular}{|l|l|l|l|}
\hline Level of Taxonomy & Definition & Student Roles & Action Verbs \\
\hline $\begin{array}{l}\text { Knowledge } \\
\text { (The most concrete) }\end{array}$ & Recall of specific information & $\begin{array}{l}\text { Responds } \\
\text { Absorbs }\end{array}$ & $\begin{array}{l}\text { Tell } \\
\text { Define }\end{array}$ \\
\hline Comprehension & $\begin{array}{l}\text { Understanding of } \\
\text { communicated information }\end{array}$ & $\begin{array}{l}\text { Explains } \\
\text { Translates }\end{array}$ & $\begin{array}{l}\text { Change } \\
\text { Describe }\end{array}$ \\
\hline Application & $\begin{array}{l}\text { Use of rules and theories in new } \\
\text { situations }\end{array}$ & $\begin{array}{l}\text { Demonstrates } \\
\text { Solves problems }\end{array}$ & $\begin{array}{l}\text { Apply } \\
\text { Demonstrate }\end{array}$ \\
\hline Analysis & $\begin{array}{l}\text { Breaking down information into } \\
\text { parts }\end{array}$ & $\begin{array}{l}\text { Discuss } \\
\text { Uncovers }\end{array}$ & $\begin{array}{l}\text { Investigate } \\
\text { Categorize }\end{array}$ \\
\hline Synthesis & $\begin{array}{l}\text { Putting together of ideas into a } \\
\text { new plan }\end{array}$ & $\begin{array}{l}\text { Relates } \\
\text { Contrasts }\end{array}$ & $\begin{array}{l}\text { Create } \\
\text { Invent }\end{array}$ \\
\hline $\begin{array}{l}\text { Evaluation } \\
\text { (The most abstract) }\end{array}$ & $\begin{array}{l}\text { Judging the value of materials } \\
\text { or ideas }\end{array}$ & $\begin{array}{l}\text { Judges } \\
\text { Debates }\end{array}$ & $\begin{array}{l}\text { Decide } \\
\text { Assess }\end{array}$ \\
\hline
\end{tabular}

\section{Results and Discussion}

Ten out of thirty two observed classes were in intermediate level. In this paper, studies in reading activities have done on three phases, namely, pre-reading, during-reading, and after-reading. Since intermediate learners are cognitively more developed than the elementary ones, they can benefit from higher-order thinking processes. Teachers in intermediate level mainly resorted to explanations and rote-learning processes such as repetition. Teachers most often asked learners to memorize new vocabularies or grammar points and to describe particular information presented in reading section. Learners were required to understand teacher's monologue and to show their understanding in the similar activities by explaining it to the teacher. After close scrutiny, it was recognized that most teachers use the verbs which were basically in knowledge and comprehension category. Table 2 is the list of action verbs teachers used for intermediate learners.

Since learners in intermediate level are not so fluent and competent in using the language to communicate or to understand new information, the authoritative role of the teacher is most vividly seen in this level. Learners are more dependent on the teacher. They cannot take the lead by themselves and they see the teacher as the only person whom they should listen to. In intermediate levels, as Table 2 represents, the teacher mostly used the action verbs which are related to concrete end of the taxonomy which is called knowledge. The results show that 73 out of 163 verbs used by teachers in various phases of teaching reading are related to knowledge level (most action verbs are placed in this level). Although information or knowledge is recognized as an important outcome of education, very few teachers would be satisfied to regard this as the primary or the sole outcome of instruction (Bloom, Engelhart, Furst, Hill, \& Krathwohl, 1956). Comprehension comes next with 50 action verbs in total number of data. Unfortunately, thinking which is related to evaluation level is the most ignored one. Moon (2008) believed that, "although thinking must surely be at the heart of education, it is not often explicitly taken into consideration in pedagogy" (p. vii). In order to improve learners' higher-order thinking processes, it is helpful to take into account the following recommendations: 
- Learners should be taught to reflect on an issue or happening

- Learners should be encouraged to analyze writers' point of view in various ways

- Learners ought to synthesize new and incomplete ideas and information

- Learners should take into account the stand point of writers when reading a text

- Teachers should help learners to be aware of metacognitive thinking

- It is good to manage workshops in which learners can extend their thinking

- Learners should compare and contrast their views with those of a partner

Table 2. Typical teachers' action verbs in reading skill: Intermediate level

\begin{tabular}{|c|c|c|c|c|}
\hline Phase & Action verbs & Category & Frequency & Sample sentence \\
\hline \multirow{4}{*}{ Pre-reading } & $\begin{array}{l}\text { List } \\
\text { Define } \\
\text { Repeat } \\
\text { Remember }\end{array}$ & Knowledge & $\begin{array}{l}5 \\
11 \\
7 \\
8\end{array}$ & $\begin{array}{l}\text { Please repeat after the } \\
\text { teacher or/and the tape }\end{array}$ \\
\hline & $\begin{array}{l}\text { Explain } \\
\text { Paraphrase } \\
\text { Infer }\end{array}$ & Comprehension & $\begin{array}{l}8 \\
4 \\
5\end{array}$ & $\begin{array}{l}\text { Paraphrase the topic in other } \\
\text { words }\end{array}$ \\
\hline & Compare & Analysis & 8 & $\begin{array}{l}\text { Compare the first sentence of } \\
\text { each paragraph }\end{array}$ \\
\hline & Imagine & Synthesis & 9 & $\begin{array}{l}\text { Imagine you are in the same } \\
\text { situation }\end{array}$ \\
\hline \multirow{4}{*}{ During-reading } & $\begin{array}{l}\text { Repeat } \\
\text { Remember }\end{array}$ & Knowledge & $\begin{array}{l}10 \\
5\end{array}$ & $\begin{array}{l}\text { Repeat each sentence after } \\
\text { the tape }\end{array}$ \\
\hline & $\begin{array}{l}\text { Explain } \\
\text { Paraphrase }\end{array}$ & Comprehension & $\begin{array}{l}6 \\
7\end{array}$ & $\begin{array}{l}\text { Explain the would-be } \\
\text { reasons of an event }\end{array}$ \\
\hline & Compare & Analysis & 4 & $\begin{array}{l}\text { Compare the main idea of } \\
\text { the first and the second } \\
\text { paragraph }\end{array}$ \\
\hline & Judge & Evaluation & 5 & $\begin{array}{l}\text { Judge whether the point } \\
\text { mentioned is right or wrong }\end{array}$ \\
\hline \multirow{5}{*}{ After-reading } & $\begin{array}{l}\text { Define } \\
\text { Tell } \\
\text { Name } \\
\text { Repeat }\end{array}$ & Knowledge & $\begin{array}{l}9 \\
5 \\
4 \\
9\end{array}$ & Tell me what your name is \\
\hline & $\begin{array}{l}\text { Explain } \\
\text { Paraphrase } \\
\text { Infer }\end{array}$ & Comprehension & $\begin{array}{l}10 \\
8 \\
2\end{array}$ & $\begin{array}{l}\text { Infer what would happen at } \\
\text { the end }\end{array}$ \\
\hline & Use & Application & 8 & $\begin{array}{l}\text { Use the same structure to } \\
\text { build new sentences }\end{array}$ \\
\hline & Contrast & Analysis & 4 & $\begin{array}{l}\text { What is the contrast between } \\
\text { two line of reasoning }\end{array}$ \\
\hline & Evaluate & Evaluation & 2 & $\begin{array}{l}\text { Give some criteria to } \\
\text { evaluate the problems }\end{array}$ \\
\hline
\end{tabular}

Freire (1970) has divided education into two types; in one type, students are like bank accounts that should be filled with as much knowledge as possible. In this banking-concept model of education, students are the passive receivers of knowledge without questioning or discussing the issues. They are educated in a way that rejection is considered as a sin. In the second type, which is more liberal, and is referred to as problem-posing education, students are allowed to think about and discuss the process of learning without giving them all the 
information. This problem-solving kind of education is the one which is diminishing in educational systems of many countries. To add salt to the injury, it is claimed that in educational systems of most schools, knowledge and remembering are the only goals of education (Sha'bani, 2005), which hearkens back to the banking-concept model of education.

A good learner, according to banking-concept model of education, is a person who is able to repeat more closely to the word being taught or a person who is able to remember words or sentences longer. In intermediate level, it seems that the only category that is mostly used by the teachers is knowledge. How about application of that knowledge? How about processes which lead to insight and development in thinking such as synthesis of information and decision-making? There was little interaction or group work among intermediate learners while participating in reading activity. These processes can help learners as well as the instructor in that learners can use the acquired information and internalize it and the teacher can recognize whether learners have understood the passage efficiently and practically.

Brunner, one of the leading psychologists in the realm of cognitive learning, proposed his theories in the framework of discovery learning (Brunner, 1968). He believed that the process of learning should help individuals to learn better and more. Imposing learners with so much information is not a decent way of teaching, according to Brunner; learners should come up with solutions for the problems they encounter during the process of learning. In teaching reading, teachers should not provide all the answers but they should help learners to increase their insight so that they would be able to take the lead of their learning even in the absence of the teacher. Table 3 shows the total number of action verbs used in different phases of reading skill.

Table 3. Distribution of teachers' action verbs in intermediate level

\begin{tabular}{|c|c|c|c|c|}
\hline \multirow{2}{*}{ Level } & \multicolumn{3}{|c|}{ Phase } & \multirow{2}{*}{ Total } \\
\cline { 2 - 5 } & Pre-reading & During-reading & After-reading & 73 \\
\hline Knowledge & 31 & 15 & 27 & 50 \\
\hline Comprehension & 17 & 13 & 20 & 8 \\
\hline Application & 0 & 0 & 8 & 16 \\
\hline Analysis & 8 & 4 & 4 & 9 \\
\hline Synthesis & 9 & 0 & 0 & 7 \\
\hline Evaluation & 0 & 5 & 61 & $\mathbf{1 6 3}$ \\
\hline Total & 65 & 37 & 2 & \\
\hline
\end{tabular}

Table 3 reveals another considerable finding. In pre-reading activities most action verbs are related to knowledge level. Teachers in this phase of teaching reading, give required information to learners so that they can come up with difficult points (e.g., new vocabularies and complex structures). In during and after-reading phases, action verbs related to evaluation level are used more frequently. Therefore, thinking processes in intermediate level are mostly used in during and after-reading activities (although of low frequency). However, most of the verbs are related to knowledge level which conveys that the direction of teacher-learner relationship in intermediate classes is to a great degree unidirectional. It is the teacher that 
provides information and learners have little contribution. It should be mentioned that knowledge is not totally useless. It is the base of all higher-level thinking processes, but teachers should not indulge providing all the information for learners. The importance of thinking is so much that Descartes mentioned "I think so I am." Generally, the following are concluded from Table 3:

- Thinking processes are not taken into account in intermediate level

- It is better to use more thinking processes in after-reading activities

- The knowledge which is acquired has little applicability

Table 4. Typical teachers' action verbs in reading skill: Upper-Intermediate level

\begin{tabular}{|c|c|c|c|c|}
\hline Phase & Action verbs & Category & Frequency & Sample sentence \\
\hline \multirow{4}{*}{ Pre-reading } & $\begin{array}{l}\text { Define } \\
\text { Repeat } \\
\text { Tell } \\
\text { Remember } \\
\end{array}$ & Knowledge & $\begin{array}{l}7 \\
6 \\
9 \\
5 \\
\end{array}$ & Tell me what's in your bag? \\
\hline & $\begin{array}{l}\text { Describe } \\
\text { Paraphrase }\end{array}$ & Comprehension & $\begin{array}{l}4 \\
8\end{array}$ & $\begin{array}{l}\text { Describe one case in point } \\
\text { related to the pictures }\end{array}$ \\
\hline & $\begin{array}{l}\text { Imagine } \\
\text { Propose }\end{array}$ & Synthesis & $\begin{array}{l}3 \\
3 \\
\end{array}$ & $\begin{array}{l}\text { Propose another topic which } \\
\text { has the same denotation }\end{array}$ \\
\hline & $\begin{array}{l}\text { Judge } \\
\text { Critique }\end{array}$ & Evaluation & $\begin{array}{l}4 \\
5 \\
\end{array}$ & $\begin{array}{l}\text { Criticize the situation using } \\
\text { your logic }\end{array}$ \\
\hline \multirow{5}{*}{ During-reading } & $\begin{array}{l}\text { Define } \\
\text { Repeat }\end{array}$ & Knowledge & $\begin{array}{l}5 \\
9 \\
\end{array}$ & $\begin{array}{l}\text { Define the meaning of new } \\
\text { expressions }\end{array}$ \\
\hline & $\begin{array}{l}\text { Explain } \\
\text { Paraphrase }\end{array}$ & Comprehension & $\begin{array}{l}7 \\
8\end{array}$ & Explain the writer view point \\
\hline & $\begin{array}{l}\text { Use } \\
\text { Apply }\end{array}$ & Application & $\begin{array}{l}5 \\
4 \\
\end{array}$ & $\begin{array}{l}\text { Use new words to make new } \\
\text { sentences }\end{array}$ \\
\hline & Compare & Analysis & 6 & $\begin{array}{l}\text { Compare the culture of your } \\
\text { country with the one given in } \\
\text { the passage }\end{array}$ \\
\hline & $\begin{array}{l}\text { Justify } \\
\text { Debate } \\
\text { Judge }\end{array}$ & Evaluation & $\begin{array}{l}4 \\
5 \\
4\end{array}$ & $\begin{array}{l}\text { Justify the values or ideas of } \\
\text { the writer }\end{array}$ \\
\hline \multirow{6}{*}{ After-reading } & $\begin{array}{l}\text { Tell } \\
\text { List } \\
\text { Remember }\end{array}$ & Knowledge & $\begin{array}{l}5 \\
3 \\
7\end{array}$ & $\begin{array}{l}\text { List some other familiar } \\
\text { situations }\end{array}$ \\
\hline & $\begin{array}{l}\text { Paraphrase } \\
\text { Infer } \\
\text { Explain }\end{array}$ & Comprehension & $\begin{array}{l}9 \\
7 \\
6\end{array}$ & $\begin{array}{l}\text { Paraphrase the passage } \\
\text { using your own words }\end{array}$ \\
\hline & $\begin{array}{l}\text { Demonstrate } \\
\text { Report }\end{array}$ & Application & $\begin{array}{l}5 \\
3\end{array}$ & $\begin{array}{l}\text { Report some other problems } \\
\text { that may occur }\end{array}$ \\
\hline & $\begin{array}{l}\text { Examine } \\
\text { Compare }\end{array}$ & Analysis & $\begin{array}{l}4 \\
6\end{array}$ & Examine the reasons \\
\hline & $\begin{array}{l}\text { Propose } \\
\text { What if }\end{array}$ & Synthesis & $\begin{array}{l}5 \\
4 \\
\end{array}$ & What if it didn't occur \\
\hline & $\begin{array}{l}\text { Judge } \\
\text { Debate } \\
\text { Justify }\end{array}$ & Evaluation & $\begin{array}{l}3 \\
5 \\
6 \\
\end{array}$ & Justify your viewpoint \\
\hline
\end{tabular}

The second group is upper-intermediate learners. Eleven classes are placed in this category. In this level, teachers still resort to controlled processes but automatic processes exist during 
various phases of reading activities. Table 4 shows teachers' action verbs in upper-intermediate level.

In upper-intermediate classes, the same trend which held true in intermediate level was recognized. Although in this level knowledge verbs occupied the most ones, with 56 out of 189 action verbs, the verbs which are related to evaluation level increased to a considerable degree - 36 out of 189. Action verbs in other categories have also increased with comparison to intermediate levels. In contrast to intermediate group, there are more action verbs of evaluation in upper-intermediate level and it can be concluded that when the proficiency increases, abstract action verbs in teachers' discourse increase too. Table 5 shows the distribution of action verbs in different phases of reading activity in upper-intermediate level:

Table 5. Distribution of teachers' action verbs in upper-intermediate level

\begin{tabular}{|c|c|c|c|c|}
\hline \multirow{2}{*}{ Level } & \multicolumn{3}{|c|}{ Phase } & \multirow{2}{*}{ Total } \\
\cline { 2 - 5 } & Pre-reading & During-reading & After-reading & 56 \\
\hline Knowledge & 27 & 14 & 15 & 49 \\
\hline Comprehension & 12 & 15 & 22 & 17 \\
\hline Application & 0 & 9 & 8 & 16 \\
\hline Analysis & 0 & 6 & 9 & 15 \\
\hline Synthesis & 6 & 0 & 14 & 36 \\
\hline Evaluation & 9 & 13 & 78 & $\mathbf{1 8 9}$ \\
\hline Total & 54 & 57 & & \\
\hline
\end{tabular}

Table 5 reveals that in upper-intermediate level, action verbs related to knowledge are more popular than other levels. In this group knowledge and comprehension are the most used levels. However, evaluation verbs have been increased considerably in comparison to intermediate learners.

The third group is advanced learners which constituted eleven classes in this study. The main purpose in these classes is that learners convey their thoughts as clearly as possible through verbal interaction. Therefore, the activities should be less controlled and learners should be able to apply their knowledge to new situations or they should assess their own progress in a decent way in order to reach autonomy. Most learners were seventeen to nineteen. In this level, learners are expected to use their knowledge to produce new ideas and to discuss topics in order to evaluate or assess the value of things. However, the findings showed that knowledge still has the first rank although verbs related to evaluation level have increased to a considerable degree. For example, for reading comprehension most of the teachers used techniques such as defining, stating, paraphrasing, or inferring information which are placed in concrete end of the Bloom's taxonomy. Table 6 provides a general view of common action verbs teachers used for advanced learners: 
Table 6. Typical teachers' action verbs in reading skill: Advanced level

\begin{tabular}{|c|c|c|c|c|}
\hline Phase & Action verbs & Category & Frequency & Sample sentence \\
\hline \multirow{5}{*}{ Pre-reading } & $\begin{array}{l}\text { Remember } \\
\text { State } \\
\text { List } \\
\text { Define }\end{array}$ & Knowledge & $\begin{array}{l}6 \\
4 \\
5 \\
7\end{array}$ & $\begin{array}{l}\text { State your feeling about the } \\
\text { picture }\end{array}$ \\
\hline & $\begin{array}{l}\text { Explain } \\
\text { Infer }\end{array}$ & Comprehension & $\begin{array}{l}8 \\
9 \\
\end{array}$ & $\begin{array}{l}\text { Infer what would happen at } \\
\text { the end of the passage }\end{array}$ \\
\hline & $\begin{array}{l}\text { Compare } \\
\text { Contrast }\end{array}$ & Analysis & $\begin{array}{l}6 \\
8 \\
\end{array}$ & $\begin{array}{l}\text { Compare two pictures with } \\
\text { each other }\end{array}$ \\
\hline & $\begin{array}{l}\text { Imagine } \\
\text { Propose }\end{array}$ & Synthesis & $\begin{array}{l}9 \\
7\end{array}$ & $\begin{array}{l}\text { Imagine the same problem } \\
\text { happens for you }\end{array}$ \\
\hline & $\begin{array}{l}\text { Judge } \\
\text { Decide } \\
\text { Debate }\end{array}$ & Evaluation & $\begin{array}{l}9 \\
6 \\
9 \\
\end{array}$ & $\begin{array}{l}\text { Debate what } \\
\text { overpopulation effects in } \\
\text { your country }\end{array}$ \\
\hline \multirow{6}{*}{ During-reading } & $\begin{array}{l}\text { Remember } \\
\text { Identify } \\
\text { Name }\end{array}$ & Knowledge & $\begin{array}{l}7 \\
3 \\
6\end{array}$ & $\begin{array}{l}\text { Name different words that } \\
\text { are related to school }\end{array}$ \\
\hline & $\begin{array}{l}\text { Restate } \\
\text { Paraphrase }\end{array}$ & Comprehension & $\begin{array}{l}6 \\
9 \\
\end{array}$ & $\begin{array}{l}\text { Paraphrase the main idea of } \\
\text { the paragraph }\end{array}$ \\
\hline & $\begin{array}{l}\text { Compare } \\
\text { Contrast } \\
\end{array}$ & Application & $\begin{array}{l}6 \\
2 \\
\end{array}$ & $\begin{array}{l}\text { Compare your view point } \\
\text { with that of a friend }\end{array}$ \\
\hline & Organize & Analysis & 2 & $\begin{array}{l}\text { Organize different solutions } \\
\text { into main categories }\end{array}$ \\
\hline & Create & Synthesis & 2 & $\begin{array}{l}\text { Create your own way of } \\
\text { dealing with the problem }\end{array}$ \\
\hline & $\begin{array}{l}\text { Select } \\
\text { Justify } \\
\text { Judge }\end{array}$ & Evaluation & $\begin{array}{l}4 \\
7 \\
5 \\
\end{array}$ & $\begin{array}{l}\text { Select those areas which are } \\
\text { in contrast to your belief }\end{array}$ \\
\hline \multirow{6}{*}{ After-reading } & $\begin{array}{l}\text { Remember } \\
\text { Tell } \\
\text { Define }\end{array}$ & Knowledge & $\begin{array}{l}7 \\
9 \\
10 \\
\end{array}$ & $\begin{array}{l}\text { Remember what you have } \\
\text { read and write it down }\end{array}$ \\
\hline & $\begin{array}{l}\text { Restate } \\
\text { Paraphrase }\end{array}$ & Comprehension & $\begin{array}{l}8 \\
13 \\
\end{array}$ & $\begin{array}{l}\text { Restate your friend's point of } \\
\text { view }\end{array}$ \\
\hline & $\begin{array}{l}\text { Use } \\
\text { Practice }\end{array}$ & Application & $\begin{array}{l}6 \\
8 \\
\end{array}$ & $\begin{array}{l}\text { Practice the words in new } \\
\text { sentences }\end{array}$ \\
\hline & $\begin{array}{l}\text { Examine } \\
\text { Compare } \\
\text { Contrast } \\
\text { Classify } \\
\end{array}$ & Analysis & $\begin{array}{l}3 \\
5 \\
4 \\
3 \\
\end{array}$ & $\begin{array}{l}\text { Classify the cause and effect } \\
\text { relationships in different } \\
\text { categories }\end{array}$ \\
\hline & $\begin{array}{l}\text { Compose } \\
\text { Imagine }\end{array}$ & Synthesis & $\begin{array}{l}2 \\
6\end{array}$ & $\begin{array}{l}\text { Imagine you had the } \\
\text { authority to change the world }\end{array}$ \\
\hline & $\begin{array}{l}\text { Judge } \\
\text { Recommend } \\
\text { Justify } \\
\text { Critique }\end{array}$ & Evaluation & $\begin{array}{l}8 \\
5 \\
3 \\
5\end{array}$ & $\begin{array}{l}\text { Recommend some solutions } \\
\text { to solve the problem }\end{array}$ \\
\hline
\end{tabular}

In comparison with intermediate and upper-intermediate levels, in advanced level the teachers have used the most action verbs $(N=257)$. Table 6 points out that teachers talk more with proficient learners. Moreover, learners in advanced levels are high input generators in that they initiate interaction (Seliger, 1983). The most considerable difference between advanced learners and the other two groups of learners is that in advanced level, the use of 
evaluation verbs has increased significantly. It can be concluded that using higher-level thinking processes may have a close relationship with learners' proficiency level. In other words, since learners are more fluent in advanced levels, the teacher has more opportunity to use higher-level thinking processes such as judging and criticizing. It has significant implications for teachers and researchers. There may be a question whether higher-level thinking has any relationship with oral proficiency? Is it possible for a lower-level learner to engage as freely as advanced learners in abstract cognitive abilities? Table 7 shows the total number of action verbs in different phases of reading activity in advanced classes:

Table 7. Distribution of teachers' action verbs in advanced level

\begin{tabular}{|c|c|c|c|c|}
\hline \multirow{2}{*}{ Level } & \multicolumn{3}{|c|}{ Phase } & \multirow{2}{*}{ Total } \\
\cline { 2 - 5 } & Pre-reading & During-reading & After-reading & 64 \\
\hline Knowledge & 22 & 16 & 26 & 53 \\
\hline Comprehension & 17 & 15 & 21 & 22 \\
\hline Application & 0 & 8 & 14 & 31 \\
\hline Analysis & 14 & 2 & 15 & 26 \\
\hline Synthesis & 16 & 2 & 8 & 61 \\
\hline Evaluation & 24 & 16 & 21 & $\mathbf{2 5 7}$ \\
\hline Total & 93 & 59 & 105 & \\
\hline
\end{tabular}

In teaching reading, in advanced level, there is more opportunity for learners to share their knowledge since they are more competent and they can use language metaphorically. Table 7 reveals that teachers in pre-reading phase use evaluation verbs more than other verbs. Twenty four out of 93 verbs are related to evaluation which is at the first rank. This result sheds light on the questions which were proposed earlier in the article. It seems that higher-level thinking processes have close relationship with language proficiency. If it would be the case, which the results of this study proved to be so, constructivist view of language is emphasized. In other words, language shapes thinking. The more proficient a student is, the more that person is going to engage in higher-level thinking processes such as evaluation. This is more related to the concept of the zone of proximal development (ZPD). According to ZPD, if the teacher provides suitable tools for learners, they are able to go beyond their existing knowledge; language can be a powerful tool for providing such a leap in the process of learning. Figure 1 shows distribution of action verbs in different learners' proficiency levels.

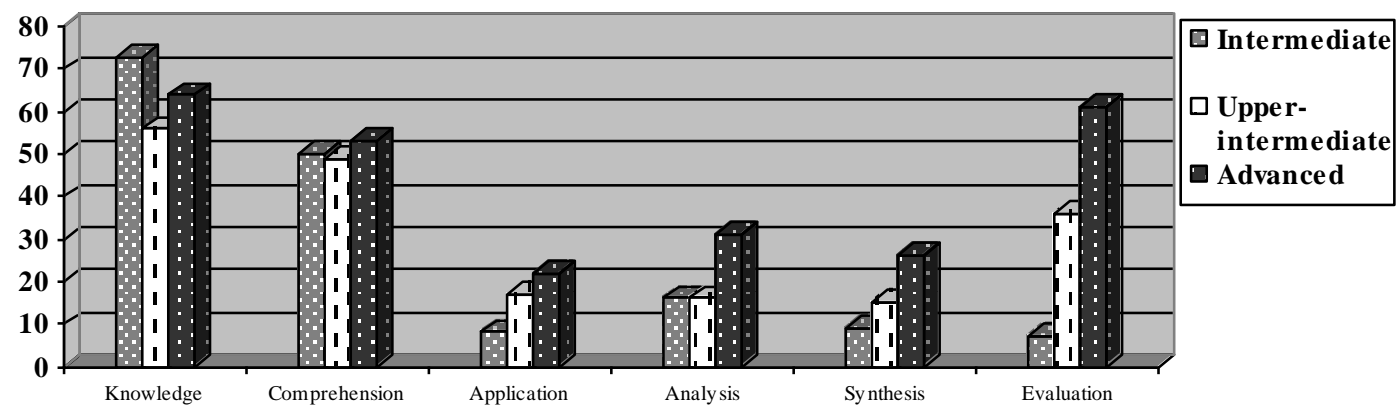

Figure 1. Distribution of action verbs according to learners' proficiency levels Proponents of cognitive psychology advocated that learning is the result of cognition, 


\section{Macrothink}

perception, and insight. From this view point, to facilitate the process of recall and to internalize information, new knowledge should be integrated to the existing knowledge. However, Figure 1 shows that in current EFL classes, concepts such as insight and active participation, which are related to abstract side of the taxonomy, are nearly overlooked to a great degree. One of the questions of this study was: "what is the main concern of teachers while teaching reading?" The findings of this study revealed that while presenting reading in the class, most EFL teachers are inclined to use concrete activities such as those related to knowledge and comprehension. As it is revealed in Figure 1, higher-level thinking processes such as synthesis and evaluation are kept in minimum. Cognitivists claimed that learning is a permanent and internal process. Having said that, human beings always try to search the environment and discover covert phenomena. This self-discovery is of paramount importance for shaping human beings since they define themselves with these findings. In the same vein, teachers should encourage and help learners to increase their insight and to provide learners with questions so that they use the acquired knowledge to solve problems. Figure 2 shows total percentage of different cognitive levels in teacher discourse in reading activity.

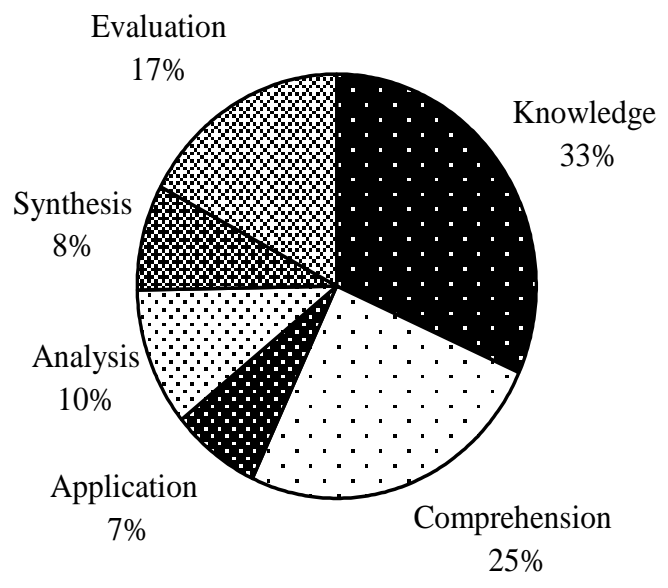

Figure 2. Total percentage of levels recognized in teacher discourse in reading skill

There have been various definitions for learning throughout the history of language teaching. Most people and many teachers define learning as gaining knowledge or information (Sha'bani, 2005). Educators sometime equate learning with transferring information from one person, who is usually the teacher, to another one who is the student. In this unidirectional process, the teacher plays an important role without him/her, there would be no learning. According to Ausubel (1964), learning via memorization and repetition, does not lead to meaningful learning. Piaget (1970) believed that learners should take responsibility for their own learning otherwise there would be no learning. To put it in another way, learners should not be passive receivers of information in a one-way relationship. 
One of the questions of this study was: "which areas of thinking process are eminent during different phases of teaching reading?" Figure 2 shows that teachers' discourse during reading activity is mostly inclined toward knowledge and comprehension (58\%). Learners' voices are hardly attended to. Another question of this study was: "do learners learn how to apply the knowledge they require when reading a passage?" According to Figure 2, the process of teaching reading is not so functional since learners are not provided with situations to apply what they have learned during reading activity (only $7 \%$ of total verbs). Therefore, the knowledge transferred from the teacher to learners has little to do with their real life and is not authentic.

Figure 2 reveals that learning in neither case is integrated with application of that knowledge. Only $7 \%$ of the whole action verbs used by the teachers required learners to apply what they have been taught (knowledge) during reading. Learners should be able to combine different parts in order to be creative in their use of language. Imposing learners to knowledge most of the time kills the creativity within learners.

The findings of this study are in the same line with what Kumaravadivelu (2003b) depicted as common stereotypes of Asian students. According to him, Asian students: (1) are obedient to authority, (2) lack critical thinking skills, and (3) do not participate in classroom interaction (pp. 710-713). One of the questions of this research was: "does the instruction liberate students or make them addicted to obey the teacher unquestionably?" With answering this question it is also possible to answer another question: "what is the role of learners in different phases of reading activities?" As it was presented in Figure 1, in all three levels of proficiency - intermediate, upper-intermediate, and advanced - teachers are mostly inclined to use knowledge verbs in reading activities. This has various messages for learners; the first one is that they had little chance to talk in the class; the second one is that the process of learning is like a one-way road; and the third one is that thinking and questioning are not so welcomed-just obey.

\section{Conclusion}

In this study, the researchers tried to find the quality of teacher discourse while presenting reading in different phases using Bloom's cognitive taxonomy as the yard stick. The findings revealed that teachers, especially in intermediate and upper-intermediate levels, use action verbs that are mostly related to knowledge and comprehension. In advanced level, while teaching reading, teachers have established a balance between using knowledge verbs and more higher-level thinking processes such as evaluation. The findings of this study deemphasize the principles of cognitive psychologists in that thinking is not a prerequisite for language but the reverse came true. After investigating the action verbs used by teachers in different levels, it was found that in advanced levels, learners are more imposed to higher-level thinking processes. This may be for the sake of their proficiency in English not because of their cognitive development. In other words, learners can leap from their existing stage of development to higher levels by using mediating tools such as language. 
Using knowledge and comprehension verbs as the main part of the syllabus is not a satisfactory fashion of increasing learners' proficiency level. According to Gestalt psychology, learning is defined as acquiring new insights or changing in previous way of thinking. Having said that, learners should be active participants during activities in the class and they should share their ideas in order to come up with new insights or to upgrade their existing experiences. Advocating knowledge as the only means of establishing relationship with learners, teachers make learners addictive to accept a passive entity.

Another important point is the concept of feedback. In intermediate and upper-intermediate levels learners receive much lower feedback than their advanced counterparts. In advanced levels, since learners are not so bound to the authoritative role of teachers - as intermediate and upper-intermediate tend to be-they make their voiced heard through debating and criticizing ideas and in this way expose themselves to more feedback either from the teacher or from other peers.

Finally, it should be mentioned that more studies are needed in this line of research in order to find fruitful strategies to improve the quality of interactions in current EFL classes. This would surely reduce the problems which exist when moving toward progress. Knowledge is different from insight. Teachers should be concerned to increase learners' insight. When learners just receive knowledge, they turn to consumers; however, when their insight increases, they become producers of knowledge and from this insight they would be able to solve their own as well as the others' problems.

\section{References}

Ausubel, D. (1964). Adults vs. children in second language learning: Psychological considerations. Modern Language Journal, 48, 420-424.

Bandler, R., \& Grinder, J. (1982). Reframing: NLP and the transformation of meaning. Utah: Real People Press.

Bloom, B. S., Engelhart, M. D., Furst, E. J., Hill, W. H., \& Krathwohl, D. R. (1956). Taxonomy of educational objectives - Handbook 1: The cognitive domain. New York: David Mackey.

Brown, H. D. (2007). Principles of language learning and teaching. (5 $5^{\text {th }}$ ed.). White Plains, NY: Longman.

Brunner, J. S. (1968). Toward a theory of instruction. Cambridge: Harvard University Press.

Freire, P. (1970). Pedagogy of the oppressed. New York: Seabury Press.

Inceçay, G. (2010). The role of teacher talk in young learners' language process. Procedia Social and Behavioral Sciences, 2, 277-281.

Krashen, S. (1984). Immersion: Why it works and what it has taught us. Language and Society, 12, 61-64. 
Kumaravadivelu, B. (1999). Critical classroom discourse analysis. TESOL Quarterly, 33(3), 453-484.

Kumaravadivelu, B. (2003a). Beyond methods: Macrostategies for language teaching. New Haven, CT: Yale University Press.

Kumaravadivelu, B. (2003b). Problematizing cultural stereotypes in TESOL. TESOL Quarterly, 37, 709-718.

Millrood, R. (2004). The role of NLP in teachers' classroom discourse. ELT Journal, 58(1), 28-37.

Moon, J. (2008). Critical thinking: An exploration of theory and practice. NY: Routledge.

Mortiboys, A. (2005). Teaching with emotional intelligence: a step-by-step guide for higher and further education professionals. New York, NY: Taylor \& Francis.

Piaget, J. (1970). The science of education and the psychology of the child. New York: Basic Books.

Richards, J. C., \& Rodgers, T. (2001). Approaches and methods in language teaching $\left(2^{\text {nd }}\right.$ ed.). New York: Cambridge University Press.

Richards, J. C., \& Schmidt, R. (2002). Dictionary of language teaching \& applied linguistics $\left(3^{\text {rd }}\right.$ ed.). Pearson Education.

Seliger, H. (1983). Learner interaction in the classroom and its effects on language acquisition. In H. Seliger \& M. Long (Eds.), Classroom oriented research in second language acquisition. Rowley, MA: Newbury House.

Sha'bani, H. (1384/2005). Instructional skills: Methods and techniques of teaching. SAMT Publications.

Shrum, J. L., \& Glisan, E. (1994). Teacher's handbook: Contextualized language instruction. Boston, MA: Heinle \& Heinle.

Turner, J. C., Meyer, D. K., Midgley, C., \& Patrick, H. (2003). Teacher discourse and sixth graders' reported affect and achievement behaviors in two high-mastery/high-performance mathematics classrooms. The Elementary School Journal, 103(4), 357-382.

Vygotsky, L. (1962). Thought and language. Cambridge, MA: Massachusetts Institute of Technology Press.

Webb, N. M., Nemer, K. M., \& Ing, M. (2006). Small-group reflections: Parallels between teacher discourse and student behavior in peer-directed groups. Journal of Learning Sciences. 15(1), 63-119. 